\title{
Human health cost of hydrogen sulfide air pollution from an oil and gas Field
}

\author{
Dinara Kenessary ${ }^{1}$, Almas Kenessary ${ }^{1}$, Ussen Ismailovich Kenessariyev ${ }^{1}$, Konrad Juszkiewicz' \\ Meiram Kazievich Amrin', Aya Eralovna Erzhanova' \\ ${ }^{1}$ Kazakh National Medical University, Almaty, Republic of Kazakhstan
}

Kenessary DU, Kenessariyev UI, Juszkiewicz KT, Amrin MK, Erzhanova AE, Kenessary AU. Human health cost of hydrogen sulfide air pollution from an oil and gas Field. Ann Agric Environ Med. 2017; 24(2): 213-216. https://doi.org/10.26444/aaem/74562

\begin{abstract}
Introduction and objective. The Karachaganak oil and gas condensate field (KOGCF), one of the largest in the world, located in the Republic of Kazakhstan (RoK) in Central Asia, is surrounded by 10 settlements with a total population of 9,000 people. Approximately $73 \%$ of this population constantly mention a specific odour of rotten eggs in the air, typical for hydrogen sulfide $\left(\mathrm{H}_{2} \mathrm{~S}\right)$ emissions, and the occurrence of low-level concentrations of hydrogen sulfide around certain industrial installations (esp. oil refineries) is a well known fact. Therefore, this study aimed at determining the impact on human health and the economic damage to the country due to $\mathrm{H}_{2} \mathrm{~S}$ emissions.

Materials and method. Dose-response dependency between $\mathrm{H}_{2}^{2} \mathrm{~S}$ concentrations in the air and cardiovascular morbidity using multiple regression analysis was applied. Economic damage from morbidity was derived with a newly-developed method, with Kazakhstani peculiarities taken into account.

Results. Hydrogen sulfide air pollution due to the KOGCF activity costs the state almost $\$ 60,000$ per year. Moreover, this is the reason for a more than $40 \%$ rise incardiovascular morbidity in the region.

Conclusion. The reduction of hydrogen sulfide emissions into the air is recommended, as well as successive constant ambient air monitoring in future. Economic damage evaluation should be made mandatory, on a legal basis, whenever an industrial facility operation results in associated air pollution.
\end{abstract}

\section{Key words}

hydrogen sulfide, human health, economic damage, air pollution, oil field, Kazakhstan

\section{INTRODUCTION}

Today, secondary to the continuous industrialization of society, the anthropogenic environmental impact has increased manifold, affecting the health of the exposed population. According to the WHO reports, in 2012 globally, 3.7 million deaths were attributable to ambient air pollution. About $88 \%$ of these deaths occurred in low and middle income countries [1], especially in the former Soviet republics, including the Republic of Kazakhstan (RoK, Central Asia), where the health care services desperately need to harmonize the existing post-Soviet legal documentation with the international practices. In this connection, the main goal of the presented study is to identify the main risk factors for the occurrence of additional morbidity and mortalityin various environmentally disadvantaged areas, including oil and gas facilities like the Karachaganak field (KOGCF) discovered in 1979 on the territory of western Kazakhstan. With an estimated 1.2 billion tons of oil reserves, it is one of the largest oil and gas condensate fields in the world.

In view of the continuous emissions of combustion products from the field, for more than 20 years the air quality and human health have been continuously monitored in the nearest villages $(5-15 \mathrm{~km})$ with a total population of 9,000 people. Moreover, the health status of the exposed population was compared with that of Alexandrovka village, situated at a significant distance $(50 \mathrm{~km})$ from the field, but which is similar to the exposed villages according to the climate, geographic position, socio-economic, gender and age parameters $[2,3,4]$.

The sociological survey made by Alikeeva in 2009 in Berezovka, the nearest village (5 $\mathrm{km}$ from the field), showed that over $90 \%$ of respondents mentioned a specific odour in the air: oil products (12\%), ammonia (12\%), and especially rotten eggs (73\%) [5]. As explained by Hirsch et al., the odour of rotten eggs is typical for hydrogen sulfide $\left(\mathrm{H}_{2} \mathrm{~S}\right)$. Inhalation of air containing even a small amount of hydrogen sulfide causes dizziness, headache, and nausea, while significant concentrations lead to convulsions, pulmonary oedema, coma, coma, and even death [6].

In 2006, Erzhanova, with the use of multiple regression analysis between morbidity and concentrations of chemical elements in the air of Berezovka village confirmed the influence of hydrogen sulfide chronic exposure on the occurrence of additional cases of cardiovascular morbidity [7].

Human health risk assessment from the KOGCF emissions, based on modeled data (Kenessariyev et al., 2011) did not include hydrogen sulfide in their air pollutants priority list due to an insufficient proportion (less than 1\%) of total emissions, and low expected chronic concentrations of chemicals that lead to insignificant health risk $(\mathrm{HQ}<1)[8]$. However, due to numerous complaints from the inhabitants of the nearby villages, the decision was made to include hydrogen sulfide into the list of chemicals to be constantly monitored. 


\section{MATERIALS AND METHOD}

Data on $\mathrm{H}_{2} \mathrm{~S}$ was collected using the environmental monitoring stations (EMS) installed in the above-mentioned villages.

Brief description of the EMS. Continuous monitoring of ambient air was carried out with the help of 14 EMS that automatically collected data every 10 seconds. The data from EMS may be averaged for any length interval.The minimum detection limit is less than $0.00056 \mathrm{mg} / \mathrm{m}^{3}$. The stations are connected to the emergency response services, thus permitting timely alert to the local governments (akimats) and population when excessively high concentrations of pollutants, hazardous for the health and life of the population, are detected [9].

Determination of additional cardiovascular morbidity. According to Erzhanova A. [7], an increase in the daily average concentration of $\mathrm{H}_{2} \mathrm{~S}$ by $0.001 \mathrm{mg} / \mathrm{m}^{3}$ increases cardiovascular morbidity by 1.1 times (by $0.002 \mathrm{mg} / \mathrm{m}^{3}$, by 2.2 times, respectively). In this case, a 2 times increase means that $50 \%$ of general morbidity $(M)$ is an additional morbidity due to increased concentration of $\mathrm{H}_{2} \mathrm{~S}(\mathrm{Ma})$. Therefore, additional morbidity in percentage $(\mathrm{Ma} \%)$ is a multiplication of quantity of times of increase $(k)$ by $50 \%$, divided by 2 times. Thus, additional cardiovascular incidence $(\mathrm{Ma})$ was calculated with the next formula:

\section{$M a=M^{*} M a \% / 100 \%$ $M a \%=k^{\star} 50 \% / 2$}

Economic damage evaluation. Economic damage from morbidity is the sum of multiplication of a single case morbidity cost $\left(M c_{y}\right)$ and additional morbidity risk $(M r)$, calculated separately for each age group $(y)-$ children, adolescents, adults, and seniors.

$$
E D m=\Sigma M c_{y}{ }^{*} M r_{y}
$$

Single case morbidity cost is the sum of the cost of a treated case (TC), sick-pay (SIC), disability benefits (SSC), and loss of tax revenue to the budget and extra-budgetary funds $(T R L)$ :

$$
M c_{y}=T C+S I C+S S C+T R L
$$

Treated case cost is equal to the medical-economic tariffs, officially approved by the State in 2011 [10]. Sick pay cost was calculated by multiplying the cost of one day of disability according to the sicklist (s), number of lost days of work (d), and coefficient of employed peoples' share in the study group $\left(\mathrm{k}_{\mathrm{w}}\right)$. Disability benefits cost was not calculated due to the lack of data on disability from the investigated diseases. Loss of tax revenue to the budget due to sickness was calculated by multiplying $d$ to $k_{w}$ and the average value of the total income tax attributable to the spent man-day $(\mathrm{t})$. This t-value consists of corporate income tax revenues $\left(\mathrm{t}_{\mathrm{ci}}\right)$, personal income tax revenues $\left(\mathrm{t}_{\mathrm{pi}}\right)$ and single social tax revenues $\left(\mathrm{t}_{\mathrm{ss}}\right)$, calculated as follows:

where:

$$
t=\left(t_{c i}+t_{p i}+t_{s s}\right) /\left(d_{w} * Q_{w}\right.
$$

$\mathrm{d}_{\mathrm{w}}$ - quantity of working days in a year;

$Q_{w}$ - quantity of working people in Kazakhstan for 2012 .

\section{RESULTS}

Maximum average monthly concentrations of hydrogen sulfide in some of the selected villages exceeded the reference point

\begin{tabular}{|c|c|c|}
\hline $\begin{array}{l}\text { Selected rural } \\
\text { ambulance(outpatient } \\
\text { clinic)(RA), named by } \\
\text { location }\end{array}$ & $\begin{array}{l}\text { Maximum monthly } \\
\text { average concentration in } \\
2012, \mathrm{mg} / \mathrm{m}^{3}\end{array}$ & $\begin{array}{l}\text { Above reference point } \\
\text { village concentration, } \\
\mathrm{mg} / \mathrm{m}^{3}\end{array}$ \\
\hline Berezovka(EMS13-14) & 0.002 & 0.001 \\
\hline Priuralny (EMS 8) & 0.002 & 0.001 \\
\hline $\begin{array}{l}\text { Zharsuat (EMS 7) } \\
\text { (including Zhanatalap) }\end{array}$ & 0.002 & 0.001 \\
\hline Kiziltal(EMS 10-11) & 0.003 & 0.002 \\
\hline $\begin{array}{l}\text { Alexandrovka RA } \\
\text { (reference point) }\end{array}$ & 0.001 & \\
\hline
\end{tabular}
concentrations in the range of $0.001-0.002 \mathrm{mg} / \mathrm{m}^{3}$ (Tab. 1).

Table 1. $\mathrm{H}_{2} \mathrm{~S}$ monthly average highest concentrations in selected villages

Therefore, it became necessary to quantify the degree of negative health impact from excess $\mathrm{H}_{2} \mathrm{~S}$. Calculated additional cardiovascular morbidity cases caused by the increase in the maximum monthly average concentrations of $\mathrm{H}_{2} \mathrm{~S}$ equaled 67.1 cases out of total 166, including 57.2 additional cases of diseases among the working population (out of 141), 8.8 cases among seniors (out of 23) and 1.1 cases among adolescents and children (out of 2) (Tab. 2).

Table 2. Additional cardiovascular morbidity

\begin{tabular}{llcccc}
\hline \multirow{2}{*}{ Selected rural ambulance } & $\begin{array}{c}\text { Bere- } \\
\text { zovka }\end{array}$ & $\begin{array}{c}\text { Priu- } \\
\text { ralny }\end{array}$ & $\begin{array}{c}\text { Zharsuat } \\
\text { (including } \\
\text { Zhanatalap) }\end{array}$ & Kiziltal \\
\hline $\mathrm{H}_{2} \mathrm{~S}$ concentrations (C), $\mathrm{mg} / \mathrm{m}^{3}$ & 0.001 & 0.001 & 0.001 & 0.002 \\
\hline Dose-response dependence (k), times & 1.1 & 1.1 & 1.1 & 2.2 \\
\hline Percentage of Ma out of $\mathrm{M}(\mathrm{Ma} \%), \%$ & 27.5 & 27.5 & 27.5 & 55 \\
\hline \multirow{4}{*}{$\begin{array}{l}\text { General morbidity (M), } \\
\text { cases }\end{array}$} & Total & 45 & 16 & 27 & 78 \\
\cline { 2 - 7 } & adults & 41 & 12 & 21 & 67 \\
\cline { 2 - 6 } & Seniors & 4 & 4 & 6 & 9 \\
\cline { 2 - 6 } & Adolescents & 0 & 0 & 0 & 1 \\
\cline { 2 - 6 } & Children & 0 & 0 & 0 & 1 \\
\hline \multirow{3}{*}{$\begin{array}{l}\text { Additional morbidity } \\
\text { (Ma), cases }\end{array}$} & Total & 12.4 & 4.4 & 7.4 & 42.9 \\
\cline { 2 - 6 } & adults & 11.3 & 3.4 & 5.9 & 36.7 \\
\cline { 2 - 6 } & Seniors & 1.1 & 1 & 1.5 & 5.1 \\
\cline { 2 - 6 } & Adolescents & 0 & 0 & 0 & 0.55 \\
\cline { 2 - 6 } & Children & 0 & 0 & 0 & 0.55 \\
\hline
\end{tabular}

Economic damage from additional cases of cardiovascular diseases due to excess concentrations of $\mathrm{H}_{2} \mathrm{~S}$ equaled $\$ 59,610$ and was the highest among theKiziltal habitants $-\$ 37,613$ (Tab. 3).

Although the economic damage evaluation methodology used in this study might have similarities worldwide, the peculiarities of the Kazakhstani health care system, taken into consideration while designing this exact specific method, have a number of differences. In particular, medical and economic tariffs (MET) [11] were used to calculate the cost of treatment instead counting the price of one day of hospitalization multiplied by the length of stay, as made in the Russian Federation. These tariffs already include the cost of payment for the medical staff, social taxes, nutrition and drugs. The cost of MET in the case of Kazakhstan is the arithmetic mean of the arterial hypertension and coronary 


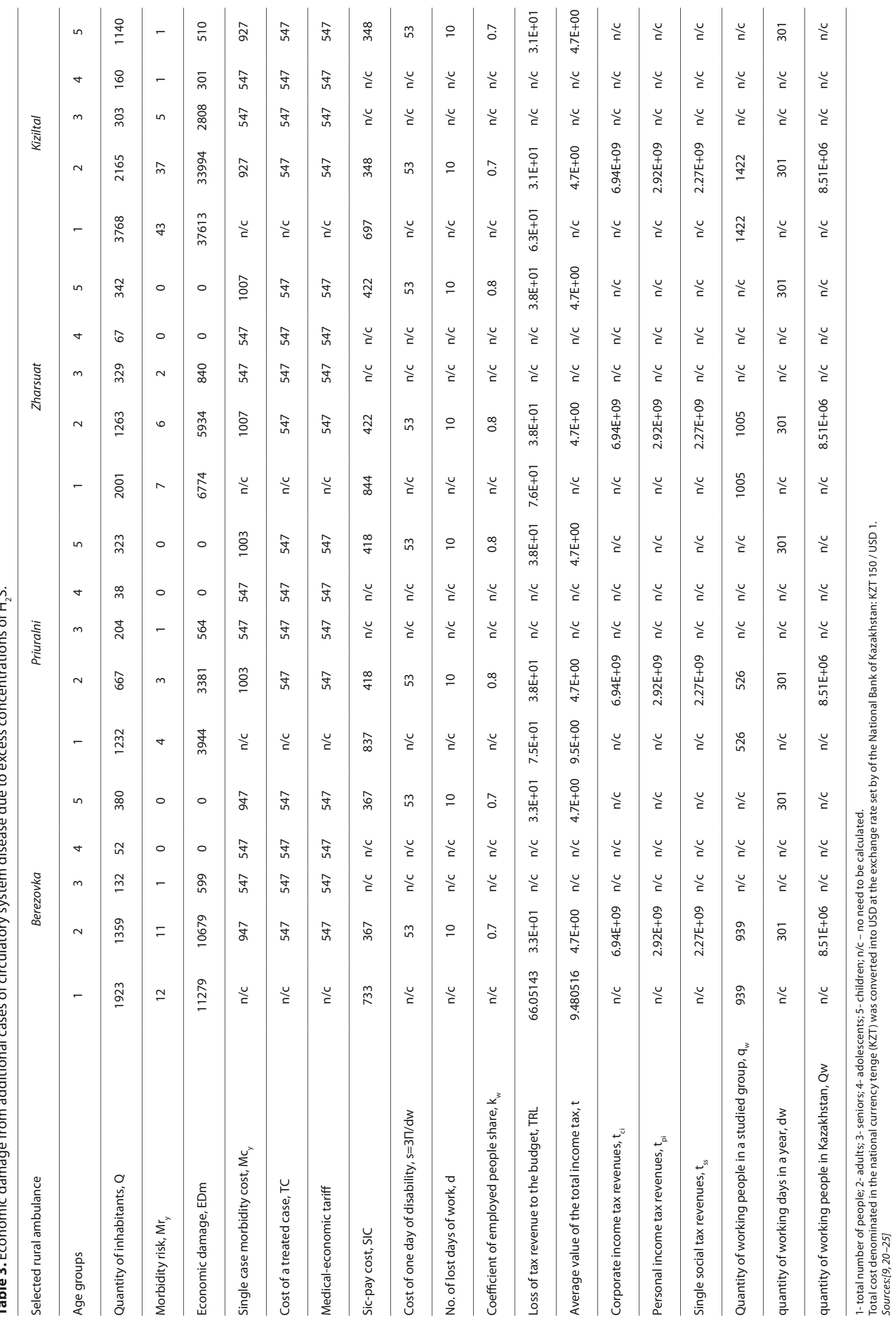


heart disease MET, since in more than $90 \%$ of cases, the above were diagnosed upon first visits of the Burlin district patients with cardiovascular diseases.

\section{DISCUSSION}

Although the negative impact of acute $\mathrm{H}_{2} \mathrm{~S}$ exposure has been known for decades, epidemiological data concerning longer-term exposures are still limited. Before the 1990s, the main regulatory assumption was that if an exposure to $\mathrm{H} 2 \mathrm{~S}$ is not fatal, there are few, if any, lasting health effects. This view, however, became medically outdated due to numerous investigations. According to research by Kilburn et al., the symptoms of chronic exposure to $\mathrm{H}_{2} \mathrm{~S}$ include pronounced deficits in balance and reaction time, dizziness, insomnia, and overpowering fatigue [12]. These investigators stated that $\mathrm{H} 2 \mathrm{~S}$ poisons the brain, and the poisoning is irreversible. Legator et al. [13] determined that over $86 \%$ of the population who underwent chronic exposure to $\mathrm{H}_{2} \mathrm{~S}$ experienced central nervous system impairment similar to that described by Kilburn et al. vs. only $26 \%$ of a reference point population (20 km from the plant). Tarver et al. also stated that people living near an industrial plant demonstrated attention deficits and an inability to process information quickly [14]. Teams of researchers at separate institutions have also discovered evidence that $\mathrm{H} 2 \mathrm{~S}$ even damages DNA [15-18].

The occurrence of low-level concentrations of $\mathrm{H}_{2} \mathrm{~S}$ around certain industrial installations is a well known fact. Low-level concentrations may occur continuously in certain industries, such as in viscose rayon and pulp production, in geothermal energy installations, and at oil refineries, where there is a high risk of exposure for the general population. A large accidental release of $\mathrm{H}_{2} \mathrm{~S}$ into the air surrounding industrial facilities can cause very severe effects, as at Poza Rica, Mexico, where 320 people were hospitalized and 22 died [19].

As seen from the research, the impact of chronic $\mathrm{H}_{2} \mathrm{~S}$ exposure has been underestimated for a long period of time. People in countries with weak environmental protection regulations are constantly under chronic exposure to numerous chemicals, including $\mathrm{H}_{2} \mathrm{~S}$, which is an important chemical for Kazakhstan, since oil mining is one of the driving forces in the country's economy.

\section{CONCLUSIONS}

Hydrogen sulfide air pollution due to the KOGCF activity costs the Kazakhstan budget almost $\$ 60,000$ per year. Moreover, this is the reason for an over $40 \%$ rise in cardiovascular morbidity in the affected villages. In this regard, the reduction of hydrogen sulfide emissions into the air is recommended, as well successive and constant ambient air monitoring in future.

It is suggested that the evaluation of economic damage should be made mandatory, on a legal basis, whenever the operations of an industrial facility result in associated air pollution.

The results of the presented research should be included in determining an expense item in the statutory payments made by an enterprise to the government, in order to rehabilitate the health of the exposed population, within the framework of a free public health care system.

\section{REFERENCES}

1. WHO databases. Burden of disease from Ambient Air Pollution for 2012. Summary of results. Available from: www.who.int/phe/health topics/outdoorair/databases/FINAL_HAP_AAP_BoD_24March2014. pdf - $91 \mathrm{k}$

2. Kenessariyev UI. Hygienic basis of assessement prognosses and development of environmental-health system at KOGCF. [dissertation]. Almaty (RoK); 1993.

3. Omarkojaeva GN. Complex assessemnet of environment quality and risk-factors of oil fields [dissertation]. Almaty (RoK);KazNMU; 2006.

4. Kurmangaliev OM. Ecological and hygienic aspects of forming pathology of the genitourinary system in RoK oil and gas condensate regions (on an example of KOGCF). [dissertation]. Almaty (RoK); 2008

5. Alikeeva GM. Hygienic assessement and prognoses of sanitarydemographic processess in KOGCF region [dissertation]. Almaty (RoK);KazNMU;2001.

6. Hirsch AR, Zavala G. Long-term effects on the olfactory system of exposure to hydrogen sulphide. Occup Environ Med 1999; 56:284-287. Available from: http://oem.bmj.com/content/56/4/284.full.pdf

7. Erzhanova AE. Mathematical modeling of the air quality effect on public health (on the example of the Karachaganak oil and gas field). Veda a vznik - 2009/2010: Proceedings of the 5th International scientific conference; 2009-2010; 27 December - 5 Jan; Prague; Czech Republic. p. 7-9.

8. Kenessariyev UI, Dosmukhametiv AT, Amrin MK, Erzhanova AE. Human health risk assessement in oil and gas condensate region. Vestnik Kaz NMU. 2012. №1: 334-336. Available from: http://kaznmu. $\mathrm{kz} /$ press/

9. Gladkih AU, Shiryaeva T, Pedorenko EN, Kamaeva TA, Kaidakova NN, et al. Established Karachaganak oil gas and condensate field sanitary protection zone; Volume-1; Kazakhstan Agency of Applied Ecology; Almaty, 2013. Project. pp. 19-20, pp. 131-135, p.202. Contract No: AP/Y/13/0272. Sponsored by KPO b.v.

10. RoK Government Decree No1400. On the remuneration system for civil servants, employees of organizations financed from the state budget, workers of state enterprises. Dec 29, 2007. Available from: http://online. zakon.kz/Document/?doc_id=30155616

11. RoK Ministry of Health Decree No936 (30.12.2011). Appendix 11. Available from: http://www.03portal.kz/images/stories/prilozheniya_ pr936_301211.pdf

12. Kilburn KH, Thrasher JD, GrayMR.Low-level hydrogen sulfide and central nervous system dysfunction. Environ Epidemiol Toxicol 1999; 1: 207-17. Available from: http://punapono.com/docs/Kilburn1.pdf

13. Legator MS, Singleton CR, Morris DL, Philips DL.Health effects from chronic low-level exposure to hydrogen sulfide.Arch Environ Health. 2001; 56(2): 123-31. Available from: http://www.ncbi.nlm.nih.gov/ pubmed/11339675

14. Tarver GA, Dasgupta PK. Oil Field Hydrogen Sulfide in Texas: Emission Estimates and Fate. Environ Sci Tech. 1997; 31: 3669-3676.

15. Matias SA, Elizabeth DW, Michael JP, Gaskins HR. Evidence That Hydrogen Sulfide Is a Genotoxic Agent. Molecular Cancer Research 2006; 4: 9-14. Available from: http://mcr.aacrjournals.org/content/4/1/9. abstract

16. Matias SA, Elizabeth DW, Gaskins HR, Michael JP. Hydrogen Sulfide Induces Direct Radical-Associated DNA Damage. Mol Canc Res. 2007; 5(5): 455-459. Available from: http://mcr.aacrjournals.org/ content/5/5/455.full?sid=eecd1bb4-0c98-493d-9655-baa48ca29a52

17. Baskar R, Li L, Moore PK. Hydrogen sulfide-induces DNA damage and changes in apoptotic gene expression inhuman lung fibroblast cells. FASEB J. 2007;21(1):247-55. Epub 2006. Available from: http://www. ncbi.nlm.nih.gov/pubmed/17116745

18. Saadat M, Zendeh-Boodi Z. Association between genetic polymorphism of GSTT1 and depression score inindividuals chronically exposed to natural sour gas. Neurosci Lett. 2008; 435(1): 65-8. doi: 10.1016/j. neulet.2008.02.008. Epub 2008.

19. Hydrogen sulfide. Geneva, World Health Organization, 1981 (Environmental HealthCriteria, No. 19). Available from: http://www.euro.who.int/_data/assets/pdf_file/0019/123076/ AQG2ndEd 6_6Hydrogensulfide.PDF

20. Statistical Annals. Kazakhstan in 2012. RoK statistics Agency. Astana. 2013. Available from: file://localhost/C:/Users/user/Downloads/1Казахстан\%20в\%202012\%20году.pdf

21. Health of the RoK and the Activities of Health Care Organizations in 2012. Statistical Book. The Ministry of Health (RoK). Astana. 2013.

22. Diagnostic and treatment protocols for diseases (intended for primary health care facilities). LBC 51.1 (2) 2. RoK Ministry of Health Decree No 655 (30.12.2005).

23. Diagnostic and treatment protocols for diseases (intended for hospitals of therapeutic type). LBC 53.5. RoK Ministry of Health Decree No 655 (30.12.2005).

24. RoK Labor Code (including amendments and additions). Art.159, paragraph 3 (04.07.2013).

25. Burlin central district hospital Statistics Division. Data on the primary morbidity and demographic indicators in 2012 